\title{
Analisis Asupan Gula, Garam dan Lemak (GGL) dari Jajanan pada Anak Sekolah Dasar Negeri dan Swasta di Kota Surabaya
}

\section{Analysis Intake of Sugar, Salt and Fat (SSF) from Snacks among Students in Public and Private Elementary School in Surabaya}

\author{
Nawang Ferry Risky Mega Puspita*, Adriyanto ${ }^{1}$
}

ABSTRAK

\begin{abstract}
Latar Belakang: Anak sekolah cenderung membeli jajanan yang dekat dengan mereka, sedangkan makanan jajanan yang tersedia di sekolah rata-rata mengandung gula, garam dan lemak dalam jumlah yang tinggi.

Tujuan: Penelitian ini bertujuan menganalisis asupan gula, garam dan lemak dari jajanan pada anak sekolah dasar negeri dan swasta.

Metode: Desain ini adalah cross sectional. Sampel penelitian sebanyak 131 siswa kelas IV dan V di SD negeri dan swasta yang dipilih dengan proportional random sampling lalu dilanjutkan dengan simple random sampling. Pengumpulan data meliputi wawacara menggunakan form Semi Quantitative Food Frequency. Analisis data dilakukan dengan uji Mann Whitney.

Hasil: Uji beda untuk asupan GGL di sekolah dasar negeri dan swasta yaitu asupan gula ( $p=0,001)$, asupan garam $(p<0,001)$ dan asupan lemak $(p<0,001)$. Kontribusi asupan GGL dari jajanan di SD negeri berturut-turut sebesar $130,6 \%, 86 \%$ dan $65,7 \%$ dari batas konsumsi GGL sehari, sedangkan asupan GGL dari jajanan di SD swasta berkontribusi berturut-turut sebesar $81,2 \%, 44 \%$ dan $35,8 \%$ dari batas konsumsi GGL sehari.

Kesimpulan: Ada perbedaan asupan GGL dari anak yang bersekolah di SD negeri dan SD swasta. Asupan GGL lebih tinggi pada anak yang bersekolah di SD negeri dibandingkan di SD swasta ditandai dengan konsumsi GGL yang melebihi 50\% dari batas konsumsi GGL sehari. Asupan GGL yang berlebihan dalam jangka waktu yang relatif lama dapat menyebabkan perubahan status gizi sehingga, asupan GGL tetap perlu dijaga agar tidak melebihi batas konsumsinya dengan cara membatasi jajanan yang manis, gurih dan berlemak serta memberikan pendidikan gizi tentang jajanan sehat bagi anak.
\end{abstract}

Kata kunci: anak sekolah, asupan gula, garam, lemak, jajanan

\section{ABSTRACT}

Background: School age children frequently buy snacks that near them, even thought snacks available in school contain an average amount of sugar, salt and fat.

Objectives: The purpose of this study was to analyze intake of sugar, salt and fat from public and private elementary school children.

Methods: This research was cross sectional design. The samples were 131 children in IV dan $V$ class public and private elementary school, taken by proportional random sampling method and simple random sampling. Data were collected by interview method used Semi Quantitative Food Frequency questionare. Data were analysed by Mann Whitney.

Results: Different test of intake sugar, salt and fat in both school were intake sugar $(p=0.001)$, intake salt $(p<0.001)$ and intake fat $p<(0.001)$. Contributed intake of sugar, salt and fat from snacks in public school were $130.6 \%, 86 \%$ and $65.7 \%$ from standart per day, even thought contributed intake of sugar, salt and fat from snacks in private school were $81.2 \%, 44 \%$ and $35.8 \%$ from standart per day.

Conclusions: The conclusion of this study showed that there was had difference intake of sugar, salt and fat between children in public and private school. Intake of sugar, salt and fat in public school higher than private school signed with intake of sugar, salt and fat more than 50\% from standart consumtion per day. Intake of sugar, salt and fat moreover standart in long periode does change nutritional status, so to prohibition obesity in children must limit consumtion snacks especially sweets, salty and fatty. Beside that, children must have education about healthy snacks.

Keywords: school age children, intake of sugar, salt, fat, snacks, nutritional status

\author{
*Koresponden: \\ nawangferry@gmail.com \\ ${ }^{1}$ Akademi Gizi Surabaya, Jl. Bendul Merisi No.126, Wonocolo, 60239, Surabaya, Jawa Timur, Indonesia
}




\section{PENDAHULUAN}

Anak usia sekolah berada pada kisaran usia 6-12 tahun $^{1}$. Usia sekolah merupakan masa pertumbuhan paling pesat kedua setelah masa balita ${ }^{2}$. Namun, anak sekolah lebih banyak terpapar oleh makanan jajanan karena hanya $5 \%$ anak sekolah yang membawa bekal dan mereka menghabiskan 1/4 waktunya di sekolah ${ }^{3}$. Umumnya anak sekolah membeli jajanan karena mereka suka dan mereka tidak memperhatikan nilai gizi dan keamanannya ${ }^{1}$.

Kandungan beberapa zat gizi seperti karbohidrat dan lemak dari jajanan umumnya lebih dominan di bandingkan dengan zat gizi lain ${ }^{4}$. Konsumsi energi, lemak dan garam yang tinggi diiringi dengan rendahnya pengeluaran energi karena kurangnya aktifitas fisik dan sedentary lifestyle dapat menyebabkan kegemukan². Kegemukan tidak hanya dipengaruhi oleh asupan makanan dan kurang aktivitas, tetapi merupakan interaksi multifaktor seperti genetik dan lingkungan antara lain gaya hidup, sosial ekonomi, aktivitas, asupan zat gizi, psikologi dan sosiokultural ${ }^{5}$.

Hasil Analisis Survei Konsumsi Makanan Individu (SKMI) (2014) ${ }^{6}$ konsumsi Gula, Garam dan Lemak (GGL) yang tinggi terdapat pada kelompok umur 5-12 tahun dan untuk sebaran tempat tinggal yang banyak mengonsumsi GGL dalam jumlah berlebih berasal dari tempat tinggal perkotaan sebesar $35,5 \%$ dibandingkan dengan pedesaan sebesar $23,9 \%$. Hal serupa juga ditemukan pada penelitian Damastuti, et al (2010) ${ }^{7}$ bahwa asupan natrium pada anak sekolah dasar di Kota Bandung jika diasumsikan mengonsumsi 1 porsi jajanan dalam 1 hari, berada pada rentang $53 \mathrm{mg} /$ hari - 3750 $\mathrm{mg} / \mathrm{hari}$ dengan rata-rata kontribusi asupan natrium sekitar 65\% dari Angka Kecukupan Gizi (AKG). Oleh karena itu penelitian ini bertujuan untuk menganalisis hubungan antara asupan gula, garam dan lemak (GGL) dari jajanan dengan status gizi pada anak sekolah.

\section{METODE}

Penelitian ini merupakan penelitian observasional dengan disain cross sectional. Lokasi penelitian di SD negeri dan swasta di Kota Surabaya. Sekolah dasar ini digunakan untuk tempat penelitian karena terdapat perbedaan karaktertistik jenis sekolah dasar yaitu negeri dan swasta serta perbedaan kondisi sosial ekonomi seperti penelitian yang dilakukan Handayani dan Sulistianah (2011) dalam Nisak (2017) ${ }^{8}$ menunjukkan bahwa $32,6 \%$ orang tua menyekolahkan anaknya di SD swasta merupakan orang tua yang memiliki pendapatan di atas rata-rata dan $67,4 \%$ orang tua yang menyekolahkan anaknya di SD negeri merupakan orang tua yang memiliki pendapatan di bawah rata-rata. Pengambilan data dilakukan pada bulan Mei 2018.

Populasi dalam penelitian ini adalah semua siswa kelas IV dan V di SD negeri dan satu kelas IV dan V di SD swasta tahun ajaran 2017/2018 berjumlah 193 siswa. Jumlah sampel secara keseluruhan yaitu 131 siswa dihitung menggunakan rumus slovin dengan besar penyimpangan maksimal yang masih bisa ditoleransi sebesar $5 \%$, sehingga tidak terdapat perhitungan sampel yang drop out. Sampel yang termasuk dalam kriteria eksklusi akan digantikan oleh responden yang lain. Kriteria inklusi dalam penelitian ini yaitu sampel berada di lokasi pada saat pengambilan data dan siswa bersedia menjadi sampel dengan tanda tangan informed consent oleh orang tua/wali. Kriteria eksklusi pada penelitian ini yaitu siswa yang sakit saat pengambilan data dan tidak bersedia ditimbang berat badan dan diukur tinggi badan saat penelitian.

Sampel diambil dengan teknik proportional random sampling untuk menentukan proporsi jumlah anak sesuai dengan masing-masing kelas di sekolah dasar dan dilanjutkan dengan pemilihan sampel dengan cara sampel acak sederhana (simple random sampling).

Data yang dikumpulkan berupa data primer dan sekunder. Data primer di dapatkan melalui wawancara langsung dengan menggunakan kuesioner. Jenis data primer yang dikumpulkan antara lain karakteristik responden (umur, jenis kelamin dan besar uang saku), data asupan yang dikumpulkan dengan Semi Quantitative Food Frequency makanan jajanan yang terdiri dari 141 jenis jajanan yang dikonsumsi dalam 1 bulan terakhir. Data sekunder terdiri dari profil sekolah dan daftar nama siswa kelas IV dan $\mathrm{V}$ yang didapatkan dari pegawai Tata Usaha.

Dalam penelitian ini, peneliti hanya meneliti makanan jajanan yang dikonsumsi selama di sekolah. Selain itu asupan GGL anak sekolah dibandingkan dengan anjuran Permenkes RI nomor 30 tahun 2013 tentang konsumsi sehari untuk gula tidak boleh melebihi 50 gram, garam tidak boleh melebihi 5 gram dan lemak tidak boleh melebihi 67 gram $^{9}$. Instrumen yang digunakan dalam penelitian antara lain kuesioner, lembar Semi-Quantitatif Food Frequency, daftar konverensi penyerapan minyak dan pedoman konverensi berat mentah dan masak.

Data pola konsumsi konsumsi Gula, Garam dan Lemak (GGL) dari makanan jajanan yang dikumpulkan dengan alat bantu Semi-Quantitatif Food Frequency (Semi-FFQ) lalu diolah dengan program nutrisurvey untuk mengetahui besar asupan Gula, Garam dan Lemak (GGL) dalam skala data rasio (gram). Analisis data asupan GGL diuji kenormalan data terlebih dahulu dengan menggunakan uji Kolmogorov-Smirnov (KStest). Apabila data yang diuji kenormalannya menunjukkan tidak berdistribusi normal maka di lakukan uji beda dengan menggunakan Mann Whitney. Penelitian ini telah mendapatkan persetujuan etik dari Komisi Etik Penelitian Kesehatan Fakultas Kesehatan Masyarakat Universitas Airlangga nomor 205-KEPK.

\section{HASIL DAN PEMBAHASAN}

\section{Karakteristik responden}

Sebagian besar responden di SD negeri berusia 11 tahun $(49,0 \%)$, sedangkan di SD swasta sebagian besar 10 tahun (51,5\%) dengan rata-rata usia 10,5 $\pm 0,6$. Kebutuhan anak usia 10-12 tahun lebih besar jika dibandingkan dengan anak usia 7-9 tahun karena pada rentang usia ini anak sedang dalam masa pertumbuhan yang pesat aktifitas fisik lebih tinggi ${ }^{10}$. 
Tabel 1. Distribusi Karakteristik Responden Penelitian

\begin{tabular}{|c|c|c|c|c|}
\hline \multirow{2}{*}{ Karakteristik } & \multicolumn{2}{|c|}{ SD Negeri } & \multicolumn{2}{|r|}{ SD Swasta } \\
\hline & $\mathbf{n}$ & $\%$ & $\mathrm{n}$ & $\%$ \\
\hline \multicolumn{5}{|l|}{ Usia } \\
\hline 9 tahun & 4 & 4,1 & 0 & 0,0 \\
\hline 10 tahun & 41 & 41,8 & 17 & 51,5 \\
\hline 11 tahun & 48 & 49,0 & 15 & 45,5 \\
\hline 12 tahun & 5 & 5,1 & 1 & 3,0 \\
\hline Total & 98 & 100,0 & 33 & 100,0 \\
\hline \multicolumn{5}{|l|}{ Jenis kelamin } \\
\hline Laki-laki & 39 & 39,8 & 14 & 42,4 \\
\hline Perempuan & 59 & 60,2 & 19 & 57,6 \\
\hline Total & 98 & 100,0 & 33 & 100,0 \\
\hline $\begin{array}{c}\text { Rata-rata besar uang saku } \\
\text { untuk membeli jajanan }\end{array}$ & \multicolumn{2}{|c|}{ Rp $4647,9 \pm 2518,2$} & \multicolumn{2}{|r|}{$\operatorname{Rp} 4681,8 \pm 1975,7$} \\
\hline Total & \multicolumn{4}{|c|}{$\operatorname{Rp} 4656,5 \pm 2385,9$} \\
\hline
\end{tabular}

Tabel 2. Distribusi Responden Berdasarkan Asupan GGL dari Jajanan di SD negeri dan SD swasta Tahun 2018

\begin{tabular}{lccc}
\multicolumn{1}{c}{ Asupan } & Mean \pm SD & Min-Max & Nilai p \\
\hline Asupan gula (gram) & & & 0,001 \\
SD negeri & $65,3 \pm 42,1$ & $0,0-256,0$ & \\
SD swasta & $40,6 \pm 16,8$ & $11,8-81,7$ & $<0,001$ \\
\hline Asupan garam (gram) & & & \\
SD negeri & $4,3 \pm 3,6$ & $0,0-23,2$ & $<0,001$ \\
SD swasta & $2,2 \pm 1,4$ & $0,4-6,2$ & \\
\hline Asupan lemak (gram) & & & \\
SD negeri & $44,0 \pm 34,8$ & $0,0-262,8$ & \\
SD swasta & $24,0 \pm 13,1$ & $9,5-72,6$ & \\
\hline
\end{tabular}

Jenis kelamin responden sebagian besar adalah perempuan dengan distribusi $60,2 \%$ di SD negeri dan $57,6 \%$ di SD swasta. Berdasarkan hasil penelitian Fitri $(2012)^{11}$ di SDN Rawamangun 01 Pagi Jakarta Timur bahwa responden perempuan (56\%) ternyata lebih sering mengonsumsi jajanan di bandingkan responden laki-laki $(50 \%)^{11}$. Hal ini sejalan dengan pendapat Mercille, et al (2010) ${ }^{12}$ bahwa konsumsi jajanan pada anak perempuan lebih besar dan dalam waktu beragam jika dibandingkan dengan laki-laki. Menurut Papalia, et al $(2007)^{13}$ hal ini bisa disebabkan karena anak laki-laki banyak menghabiskan waktu untuk olahraga.

Rata-rata besar uang saku yang digunakan untuk membeli jajanan di SD negeri dan swasta hampir sama yaitu sebesar Rp 4647,9 $\pm 2518,2$ di SD negeri dan sebesar Rp 4681,8 $\pm 1975,7$ di SD swasta. Total besar uang saku rata-rata yang digunakan untuk membeli

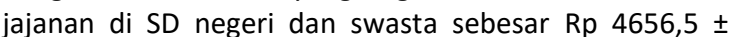
$2.85,9$. Hal ini sesuai dengan penelitian sebelumnya di SDN Ploso I-172 Surabaya bahwa rata-rata uang saku responden $\mathrm{Rp} 5894,2 \pm 3215,1^{14}$. Di SD negeri terdapat 3 responden yang tidak membawa uang saku hal ini disebabkan agar mereka tidak jajan sembarangan, sedangkan di SD swasta semua responden membawa uang saku karena sekolah menerapkan system full day school sehingga anak yang belum sarapan dari rumah diharapkan bisa membeli jajanan di sekolah.
Uang saku yang besar dapat memberikan peluang kepada anak untuk lebih banyak membeli jajanan, sedangkan perbedaan variasi uang saku yang dibawa dapat berkaitan dengan keadaan sosial ekonomi keluarga ${ }^{15}$. Distribusi karakteristik responden penelitian dapat dilihat pada Tabel 1.

\section{Asupan Gula, Garam dan Lemak (GGL) dari Jajanan}

Data asupan GGL dari jajanan yang dikonsumsi di sekolah selama satu bulan terakhir yang dikumpulkan dengan Semi-Quantitative Food Frequency. Distrubusi responden berdasarkan asupan GGL dari jajanan dapat dilihat pada Tabel 2.

Rata-rata asupan GGL dari jajanan yang dikonsumsi responden di SD negeri berturut-turut sebesar 65,3 gram, 4,3 gram dan 44 gram, sedangkan di SD swasta rata-rata asupan GGL dari jajanan berturutturut sebesar 40,6 gram, 2,2 gram dan 24 gram. Ratarata seluruh asupan GGL di SD swasta lebih rendah jika dibandingkan dengan SD negeri. Meskipun begitu konsumsi GGL sehari yang berasal dari jajanan jika di bandingkan dengan Permenkes RI No.30 tahun 2013 di SD swasta konsumsi sehari memenuhi $81,2 \%, 44 \%$ dan $35,8 \%$ dari batas GGL sehari, sedangkan di SD negeri asupan GGL dari jajanan sehari memenuhi 130,6\%,86\% dan $65,7 \%$ dari batas konsumsi GGL sehari. 
Hasil analisis uji Mann Whitney untuk perbedaan asupan GGL pada anak sekolah di SD negeri dan swasta sebesar $p=0,001$ untuk asupan gula, $p=0,000$ untuk asupan garam dan $p=0,000$ untuk asupan lemak, karena semua nilai $p<0,05$ sehingga menunjukkan bahwa ada perbedaan yang signifikan antara asupan GGL anak yang bersekolah di SD negeri dengan SD swasta. Berdasarkan hasil observasi peneliti konsumsi GGL di SD swasta cenderung lebih rendah dari SD negeri karena ketersediaan jajanan yang mengandung GGL disekolah tersebut sudah di batasi. Hal ini disebabkan karena SD swasta menerapkan sistem full day school sehingga sekolah ingin memberikan jajanan yang lebih sehat untuk muridnya. Menurut BPOM (2010) ${ }^{16}$ ketersedian jajanan di sekitar anak sekolah dapat mempengaruhi konsumsinya, karena anak usia sekolah cenderung mengonsumsi jajanan yang dekat dengan mereka.

Gula berlebih dari jajanan yang di jual di lokasi penelitian berasal dari gula yang ditambahkan pada makanan atau minuman seperti jajanan tradisional yaitu kue cucur, ongol-ongol, roti kukus dan jeli, sedangkan untuk minuman seperti es cincau, es blewah dan susu. Jajanan yang mengandung gula yang sebagian besar responden konsumsi berupa permen, biskuit kemasan, wafer lapis coklat, minuman berperisa manis sachetan, es cincau, es blewah dan susu. Hasil penelitian di beberapa negara tentang asupan gula pada anak-anak dari jajanan antara lain anak laki-laki usia 6-12 tahun di Amerika mengonsumsi 124 gram/hari, Inggris 84 gram/hari, Belanda $135 \mathrm{gram} /$ hari, Afrika Selatan 43 gram/hari dan Filipina 60 gram/hari. Selain itu di Jepang rata-rata asupan gula dari jajanan sebesar 24,7 gram $^{17}$. Tingginya asupan dapat dipengaruhi oleh berbagai faktor. Salah satunya adalah ketidaktahuan anak dan orang tua terhadap gizi, sehingga mereka salah dalam memilih makanan. Beberapa perilaku gizi yang salah pada anak sekolah yaitu jajan tidak sehat disekolah, konsumsi gula, natrium dan lemak berlebihan ${ }^{18}$.

Sebagian besar konsumsi garam di lokasi penelitian masih tergolong melebihi batas yang sudah dianjurkan. Hasil penelitian ini sejalan dengan hasil penelitian Wijayanti (2010)19 di SDN 06 Petompon Semarang bahwa rata-rata asupan natrium siswa dari jajanan sebesar 3575,5 mg/hari. Asupan garam berlebih berasal dari natrium dan Monosodium Glutamat (MSG) yang ditambahkan saat memasak makanan terutama berasal dari pedagang yang berjualan di luar sekolah. MSG merupakan Bahan Tambahan Pangan (BTP) yang di izinkan penggunaannya oleh pemerintah sebagai penyedap rasa dan aroma berdasarkan Permenkes RI Nomor.722/Menkes/Per/IX/88. Dosis maksimal penggunaan MSG yang ditetapkan badan pangan dunia sebesar $120 \mathrm{mg} / \mathrm{kgBB} /$ hari. Apabila konsumsi MSG 12 $\mathrm{g} /$ hari dapat menimbulkan gangguan lambung, gangguan tidur dan mual-mual ${ }^{20}$.

Berdasarkan data Semi-FFQ, asupan garam paling banyak berasal dari mi instan, nasi goreng, sosis, tempura, chiki dan pentol. Konsumsi natrium berlebih disebabkan karena anak menyukai makanan praktis yang mengandung tinggi garam ${ }^{21}$. Tingginya asupan natrium dapat berakibat pada peningkatan tekanan darah karena natrium bisa meretensi air sehingga jantung harus bekerja lebih keras untuk memompa darah ke seluruh tubuh ${ }^{22}$.

Konsumsi lemak di SD negeri melebihi batas standar, namun di SD swasta untuk konsumsi lemak sebagian besar normal. Hal ini disebabkan dari variasi dan jumlah jajanan berlemak yang tersedia di SD negeri lebih banyak dibandingkan dengan SD swasta. Jajanan berlemak yang tersedia di sekolah negeri antara lain biskuit pabrikan, roti maryam, chiki, kacang, tahu isi, otak-otak, kulit ayam, dadar jagung, susu dan es krim, sedangkan jajanan berlemak yang tersedia di SD swasta antara lain sate usus, usus balut tepung, nasi ayam geprek, burger mini, keripik dan chiki.

Sebagian besar jajanan berasal dari makanan yang digoreng. Makanan yang digoreng memiliki cita rasa lebih enak dibandingkan dengan yang tidak digoreng karena terjadi pemanasan protein, karbohidrat, lemak dan komponen minor lainnya. Terlebih, makanan yang tipis memiliki daya serap minyak lebih banyak dibandingkan dengan yang tebal ${ }^{21}$. Berdasarkan hasil penelitian Saadah $(2016)^{23}$ pada penjual penyetan di Tembalang Semarang menunjukkan bahwa sebanyak $65,7 \%$ pedagang yang tidak mengganti minyak goreng dari buka warung hingga tutup bahkan sebanyak $68,8 \%$ pedagang justru menambahkan minyak goreng bekas dengan minyak goreng baru selama penjualan. Minyak kelapa sawit yang digunakan secara berulang-ulang dapat merusak vitamin dan asam lemak yang terdapat pada minyak. Hal ini disebabkan oleh proses oksidasi dan polimerasi. Dampak yang timbul jika konsumsi minyak yang dipanaskan secara berulang-ulang yaitu gejala keracunan seperti iritasi saluran pencernaan, diare dan kanker ${ }^{24}$.

\section{KESIMPULAN}

Kesimpulan dari penelitian ini bahwa ada perbedaan asupan GGL dari anak yang bersekolah di SD negeri dan SD swasta. Asupan GGL lebih tinggi pada anak yang bersekolah di SD negeri dibandingkan di SD swasta ditandai dengan konsumsi GGL yang melebihi 50\% dari batas konsumsi sehari. Asupan GGL yang berlebihan dalam jangka waktu yang relatif lama dapat menyebabkan perubahan status gizi sehingga, asupan GGL tetap perlu dijaga agar tidak melebihi batas konsumsinya. Cara untuk membatasi konsumsi jajanan yang mengandung GGL yaitu dengan membatasi jajanan terutama jajanan manis, gurih dan berlemak selain itu, diharapkan adanya pendidikan gizi bagi anak terkait jajanan sehat.

\section{ACKNOWLEDGEMENT}

Penulis menyampaikan terima kasih kepada seluruh staf pengajar kelas IV dan V di SD negeri dan swasta di Kota Surabaya serta seluruh staf pengajar program studi gizi Universitas Airlangga yang telah memberikan dukungan dan bimbingan.

\section{REFERENS}

1. Briawan, D. Ilmu Gizi Teori \& Aplikasi. (EGC, 2016). 
2. Susilowati \& Kuspriyanto. Gizi Dalam Daur Kehidupan. (PT. Refika Aditama, 2016).

3. Adriani, M. \& Wirjatmadi, B. Pengantar Gizi Masyarakat. (Kencana, 2013).

4. Astawan, M. Khasiat Warna-warni Makanan. (Gramedia, 2008).

5. Trubus, R. Kegemukan Pergi \& Tak Kembali. (Niaga Swadaya, 2010).

6. Atmarita, Abas B.J., Sudikno., Moesijanti, S. Asupan Gula, Garam dan Lemak. Gizi Indon 39, 1-14 (2016).

7. Damastuti, E., Muhayatun, S., Katherina, O. \& Natalia, A. Asupan Natrium Anak Usia Sekolah Dasar di Kota Bandung. in Prosiding Seminar Nasional AAN 2010 (2010).

8. Nisak, A.J. \& Mahmudiono, T. Pola Konsumsi Makanan Jajanan di Sekolah dapat Memingkatkan Resiko Overweight / Obesitas pada Anak (Studi di SD Negeri Ploso I-172 Kecamatan Tambaksari Surabaya Tahun 2017). J. Berk. Epidemiol. 5, 311-324 (2017).

9. Kemenkes RI. Permenkes No. 30 Th 2013 Gula Garam Lemak.pdf. (2013).

10. Murniati, E. Gizi Sempurna Keluarga Sehat. (Duta Graha Pustaka, 2012).

11. Fitri, C. N. Faktor-Faktor yang Berhubungan dengan Kebiasaan Konsumsi Makanan Jajanan pada Siswa Sekolah Dasar di SDN Rawamangun 01 Pagi Jakarta Timur Tahun 2012. Skripsi 109 (2012).

12. Mercille, G., Receveur, O. \& MacAulay, A. C. Are snacking patterns associated with risk of overweight among Kahnawake schoolchildren? Public Health Nutr. 13, 163-171 (2010).

13. Papalia, D.E., Olds, S.W., \& Feldman, R. D. Human Development. (McGraw Hill, 2007).

14. Rosyidah, Z. Hubungan Antara Jumlah Uang Saku, Kebiasaan Sarapan dan Pola Konsumsi Makanan Jajanan dengan Status Gizi Lebih Anak Sekolah Dasar (Studi di SDN Ploso I-172 Kecamatan
Tambaksari Surabaya). (Universitas Airlangga, 2015).

15. Andarwulan, N., Madanijah, S., \& Zulaikhah. Monitoring Verifikasi dan Profil Keamanan Pangan Makanan Jajanan Anak Sekolah (PJAS) Nasional tahun 2008. in Monitoring Verifikasi dan Profil Keamanan Pangan Makanan Jajanan Anak Sekolah (PJAS) Nasional tahun 2008 (Southeast Asian Food and Agricultural Science and Technology (SEAFEST) Centre IPB dan Direktorat Surveilan dan Penyuluh Keamanan Pangan BPOM RI, 2008).

16. BPOM. Jajanan Anak Sekolah. Sistem Keamanan Pangan terpadu. (2010). Available at: http://www.pom.go.id. (Accessed: 1st February 2018)

17. Takeichi, H., Taniguchi, H., Fukinbara, M., Tanaka, N., Shikanai, S., Sarukura, N., \& Yamamoto, S. Sugar Intakes from Snacks and Beverages in Japanese Children. J. Nutr. Sci. Vitaminol. (Tokyo). 58, 113-117 (2012).

18. Devi, N. Gizi Anak Sekolah. (Kompas, 2012).

19. Wijayanti, E. Asupan Natrium dari Makanan Jajanan dan Tekanan Darah Siswa Sekolah Dasar. (2010).

20. Murdianti, A. \& Amaliyah. Panduan Penyiapan Pangan Sehat untuk Semua. (Kencana, 2013).

21. Astawan, M. Jangan Takut Makan Enak. petik Manfaat Semua Makanan dan Minuman. (Kompas, 2012).

22. Johnson, C. B. Dietary sodium and blood pressure in older adults. Californian J. Health Promot. 4, 25-46 (2006).

23. Saadah, A., Martini \& Yuliawat, S. Gambaran Minyak Goreng yang Dipakai Penjual Penyetan di Tembalang Semarang. J. Kesehat. Masy. 4, (2016).

24. Ketaren, N. S. Minyak \& Lemak Pangan. (Universitas Indonesia, 2005). 